\title{
1. An overview of insider trading law and policy: an introduction to the Research Handbook on Insider Trading Stephen M. Bainbridge
}

In most capital markets, insider trading is the most common violation of the securities laws. It is certainly the violation that has most clearly captured the public's imagination. Surely no other corporate or securities law doctrine has provided the plot line of as many crime thrillers and motion pictures as has insider trading.

Insider trading also long ago captured the attention of academic lawyers and economists to a degree few other topics in corporate law or securities regulation can match. As a result, it attracts scholars in fields ranging from pure legal doctrine to empirical analysis to complex economic theory. This volume collects cutting-edge scholarship in all of these areas by many of the leading experts in insider trading law and economics.

Insider trading jurisprudence is strongly skewed towards US law. This emphasis is not mere academic parochialism or chauvinism, however. The USA remains the world's largest capital market. More important for present purposes, the USA was one of the first jurisdictions to ban insider trading and remains the jurisdiction in which the ban is most energetically enforced. To be sure, insider trading bans are now on the books in many jurisdictions and there is growing global emphasis on fighting the practice. A number of the chapters in this volume focus on these developments. Much of the volume nevertheless is appropriately devoted to US law. The long history and highly developed body of US law on the subject suggest that studying the legal doctrine and policy underpinnings of the US prohibition of insider trading will reward study not only for US corporate and securities law scholars, but for those of all countries. Accordingly, this Introduction provides a foundation for the chapters that follow by setting out the basic US legal rules and the policy debate those rules have engendered.

\section{ORIGINS OF THE US PROHIBITION}

The prohibition of insider trading originally evolved in the USA as a matter of the state law fiduciary duties of corporate directors and officers. Even after the federal government took primary responsibility for securities regulation, following the adoption of the Securities Act of 1933 and the Securities Exchange Act of 1934, federal law continued to largely ignore insider trading until the late 1960s. Since then, however, a complex federal prohibition of insider trading has emerged as a central feature of modern US securities regulation.

Although the modern insider trading prohibition technically is grounded in the federal securities regulation statutes, most notably Rule $10 \mathrm{~b}-5$ promulgated by the Securities and Exchange Commission (SEC) pursuant to the authority granted it by 


\section{Research handbook on insider trading}

Section 10(b) of the Securities Exchange Act, the prohibition in fact evolved through a series of judicial decisions in a process more closely akin to common law adjudication rather than statutory interpretation. Indeed, change is one of the key distinguishing characteristics of the federal insider trading prohibition. Unfortunately, this process has been rather ad hoc, which has left the doctrine with a number of problems and curious gaps.

\section{A. The Statutory Background}

The modern prohibition is a creature of SEC administrative actions and judicial opinions, only loosely tied to the text of the key statutory provision - Securities Exchange Act $\S 10(\mathrm{~b})$ - and its legislative history. Section 10(b) provides in pertinent part that:

It shall be unlawful for any person, directly or indirectly, by the use of any means or instrumentality of interstate commerce or of the mails, or of any facility of any national securities exchange-

(b) To use or employ, in connection with the purchase or sale of any security registered on a national securities exchange or any security not so registered . . ., any manipulative or deceptive device or contrivance in contravention of such rules and regulations as the Commission may prescribe as necessary or appropriate in the public interest or for the protection of investors.

Notice two things about the statutory text. First, it is not self executing. Until the SEC exercises the rulemaking authority vested in it by the statute, $\S 10(\mathrm{~b})$ does nothing.

Secondly, nothing in $\S 10$ (b) explicitly proscribes insider trading. To the extent the 1934 Congress addressed insider trading, it did so not through $\S 10(\mathrm{~b})$, but rather through $\S 16(\mathrm{~b})$, which permits the issuer of affected securities to recover insider shortswing profits. ${ }^{2}$ Section 16 (b) imposes quite limited restrictions on insider trading. It does not reach transactions occurring more than six months apart, nor does it apply to persons other than those named in the statute or to transactions in securities not registered under $\S 12$.

If Congress intended in 1934 that the SEC use $\S 10(\mathrm{~b})$ to craft a sweeping prohibition on insider trading, the SEC was quite dilatory in doing so. Rule 10b-5, the foundation on which the modern insider trading prohibition rests, was not promulgated until 1942, eight years after Congress passed the Exchange Act. The Rule provides:

It shall be unlawful for any person, directly or indirectly, by the use of any means or instrumentality of interstate commerce, or of the mails or of any facility of any national securities exchange,

(a) To employ any device, scheme, or artifice to defraud,

(b) To make any untrue statement of a material fact or to omit to state a material fact necessary in order to make the statements made, in the light of the circumstances under which they were made, not misleading, or

(c) To engage in any act, practice, or course of business which operates or would operate as a fraud or deceit upon any person, in connection with the purchase or sale of any security. ${ }^{3}$

\footnotetext{
15 U.S.C. $\$ 78 \mathrm{j}(\mathrm{b})$.

15 U.S.C. $\$ 78 \mathrm{p}(\mathrm{b})$.

17 CFR § 240.10b-5.
} 
Note that, as with $\S 10$ (b) itself, the Rule on its face does not prohibit (or even speak to) insider trading. Indeed, it was not until 1961 that the SEC finally claimed that insider trading on an impersonal stock exchange violated Rule 10b-5. ${ }^{4}$

\section{B. The Disclose or Abstain Rule}

The modern federal insider trading prohibition fairly can be said to have begun with the SEC's 1961 enforcement action In re Cady, Roberts \& Co. ${ }^{5}$ Curtiss-Wright Corporation's board of directors decided to reduce the company's quarterly dividend. One of the directors, J. Cheever Cowdin, was also a partner of Cady, Roberts \& Co., a stock brokerage firm. Before the news was announced, Cowdin informed one of his partners, Robert M. Gintel, of the impending dividend cut. Gintel then sold several thousand shares of Curtiss-Wright stock held in customer accounts over which he had discretionary trading authority. When the dividend cut was announced, CurtissWright's stock price fell several dollars per share. Gintel's customers thus avoided substantial losses.

Cady, Roberts involved what is now known as tipping: an insider who knows confidential information does not himself trade, but rather informs - tips - someone else, who does trade. It also involved trading on an impersonal stock exchange, instead of a face-to-face transaction. As the SEC acknowledged, this made it "a case of first impression." Although Rule 10b-5 had sometimes been invoked prior to Cady, Roberts to deal with insider trading-like issues, those cases typically had involved face-to-face or control transactions rather than impersonal stock market transactions. Notwithstanding, the SEC held that Gintel had violated Rule 10b-5. In so doing, it articulated what became known as the "disclose or abstain" rule: an insider in possession of material nonpublic information must disclose such information before trading or, if disclosure is impossible or improper, abstain from trading.

It was not immediately clear what precedential value Cady, Roberts would have. ${ }^{7}$ It was an administrative ruling by the SEC, not a judicial opinion. It involved a regulated industry closely supervised by the SEC. Neither the text of the statute nor its legislative history supported-let alone mandated - a broad insider trading prohibition. ${ }^{8}$ There was a long line of state law precedent to the contrary. ${ }^{9}$

In this volume, Adam Pritchard argues that the Supreme Court's decision in SEC v. Capital Gains Research Bureau ${ }^{10}$ could have had a major impact on the development of

\footnotetext{
In re Cady, Roberts \& Co., 40 S.E.C. 907 (1961).

40 S.E.C. 907,1961 WL 3743 (1961).

Id. at $* 1$.

See, e.g., Recent Decision, 48 Va. L. Rev. 398, 403-04 (1962) ("in view of the limited resources of the Commission, the unfortunate existence of more positive and reprehensible forms of fraud, and the inherent problems concerning proof and evidence adhering to any controversy involving a breach of duty of disclosure, there is little prospect of excessive litigation evolving pursuant to [Cady, Roberts]").

8 See Stephen M. Bainbridge, Incorporating State Law Fiduciary Duties into the Federal Insider Trading Prohibition, 52 Wash. \& Lee L. Rev. 1189, 1228-34 (1995).

9 See id. at 1218-27 (analyzing cases).

10375 U.S. 180 (1963).
} 


\section{Research handbook on insider trading}

the law of insider trading post-Cady, Roberts. In his account, Capital Gains broke ground both in its approach to interpreting the federal securities laws and in its willingness to incorporate fiduciary principles into the law of insider trading. The opinion's influence was short-lived, however, as the Supreme Court reverted to a more textualist approach in securities cases.

In any case, when the Second Circuit turned Cady, Roberts into the law of the land in the seminal Texas Gulf Sulphur decision, ${ }^{11}$ it opted not to rely on fiduciary principles but rather on a purported policy requiring that investors have equal access to information. In March 1959, agents of Texas Gulf Sulphur Co., a mining corporation, began aerial surveys of an area near Timmins, Ontario. Evidence of an ore deposit was found. In October 1963, Texas Gulf Sulphur began ground surveys of the area. In early November, a drilling rig took core samples from depths of several hundred feet. Visual examination of the samples suggested commercially significant deposits of copper and zinc. Texas Gulf Sulphur's president ordered the exploration group to maintain strict confidentiality, even to the point of withholding the news from other Texas Gulf Sulphur directors and employees. In early December, a chemical assay confirmed the presence of copper, zinc, and silver. At the subsequent trial, several expert witnesses testified that they had never heard of any other initial exploratory drill hole showing comparable results. Over the next several months, Texas Gulf Sulphur acquired the rights to the land under which this remarkable ore deposit lay. In March and early April 1964, further drilling confirmed that Texas Gulf Sulphur had made a significant ore discovery. After denying several rumors about the find, Texas Gulf Sulphur finally announced its discovery in a press conference on April 16, 1964.

Throughout the autumn of 1963 and spring of 1964, a number of Texas Gulf Sulphur insiders bought stock and/or options on company stock. Others tipped off outsiders. Still others accepted stock options from the company's board of directors without informing the directors of the discovery. Between November 1963 and March 1964, the insiders were able to buy at prices that were slowly rising, albeit with fluctuations, from just under $\$ 18$ per share to $\$ 25$ per share. As rumors began circulating in late March and early April, the price jumped to about $\$ 30$ per share. On April 16, the stock opened at $\$ 31$, but quickly jumped to $\$ 37$ per share. By May 15, 1964, Texas Gulf Sulphur's stock was trading at over $\$ 58$ per share - a 222 percent rise over the previous November's price. Any joy the insiders may have taken from their profits was short-lived, however, as the SEC sued them for violating Rule 10b-5.

In what quickly became a leading opinion, the Second Circuit agreed with the SEC that Rule 10b-5 had been violated. The court held that when an insider has material nonpublic information the insider must either disclose such information before trading or abstain from trading until the information has been disclosed. Thus was born what is now known as the "disclose or abstain" rule.

The $T G S$ opinion rested on a policy of equality of access to information. The court concluded that the federal insider trading prohibition was intended to assure that "all investors trading on impersonal exchanges have relatively equal access to material

11 SEC v. Texas Gulf Sulphur Co., 401 F.2d 833 (2d Cir.), cert. denied, 394 U.S. 976 (1968). 
information." 12 Put another way, Congress purportedly intended "that all members of the investing public should be subject to identical market risks." 13

Accordingly, under $T G S$ and its progeny, virtually anyone who possessed material nonpublic information was required either to disclose it before trading or abstain from trading in the affected company's securities. If the would-be trader's fiduciary duties precluded him from disclosing the information prior to trading, abstention was the only option.

In Chiarella v. US, ${ }^{14}$ the United States Supreme Court rejected the equal access policy. Vincent Chiarella was an employee of Pandick Press, a financial printer that prepared tender offer disclosure materials, among other documents. In preparing those materials Pandick used codes to conceal the names of the companies involved, but Chiarella broke the codes. He purchased target company shares before the bid was announced, then sold the shares for considerable profits after announcement of the bid. He got caught and was indicted for illegal insider trading.

Chiarella was convicted of violating Rule $10 \mathrm{~b}-5$ by trading on the basis of material nonpublic information. The Second Circuit affirmed his conviction, applying the same equality of access to information-based disclose or abstain rule it had created in Texas Gulf Sulphur. Under the equal access-based standard, Chiarella clearly loses: he had greater access to information than those with whom he traded.

The Supreme Court reversed. In doing so, the court squarely rejected the notion that $\S 10$ (b) was intended to assure all investors equal access to information. The court said it could not affirm Chiarella's conviction without recognizing a general duty between all participants in market transactions to forego trades based on material, nonpublic information, and it refused to impose such a duty. ${ }^{15}$

Chiarella thus made clear that the disclose or abstain rule is not triggered merely because the trader possesses material nonpublic information. When a $10 \mathrm{~b}-5$ action is based upon nondisclosure, there can be no fraud absent a duty to speak, and no such duty arises from the mere possession of nonpublic information. ${ }^{16}$ Instead, the disclose or abstain theory of liability for insider trading was now premised on the inside trader being subject to a duty to disclose to the party on the other side of the transaction that arose from a fiduciary relationship between the parties. ${ }^{17}$ As applied to the facts at bar, Chiarella was not an employee, officer, or director of any of the companies in whose stock he traded. He worked solely for Pandick Press, which in turn was not an agent of any of those companies. Pandick did work mainly for acquiring companies - not the takeover targets in whose stock Chiarella traded. He therefore had no fiduciary relationship with - and thus no duty to disclose to - those with whom he traded. ${ }^{18}$
Id. at 847 .
Id. at 852 .
445 U.S. 222 (1980).
Id. at 233 .
Id. at 235 .
Id. at 230 .
18 Id. at $232-33$. 


\section{Research handbook on insider trading}

\section{Tipping}

Chiarella substantially limited the scope of the insider trading prohibition. As such, it posed the question whether anyone other than classical insiders such as directors, officers, and perhaps large shareholders could be held liable for dealing on the basis of insider information. In Dirks v. SEC ${ }^{19}$ the Supreme Court confirmed that the prohibition extended beyond classical insiders and started fleshing out the rules applicable to them. The court began by reaffirming its rejection of the equal access standard in favor of a fiduciary duty-based regime:

We were explicit in Chiarella in saying that there can be no duty to disclose where the person who has traded on inside information "was not [the corporation's] agent, ... was not a fiduciary, [or] was not a person in whom the sellers [of the securities] had placed their trust and confidence." Not to require such a fiduciary relationship, we recognized, would "[depart] radically from the established doctrine that duty arises from a specific relationship between two parties" and would amount to "recognizing a general duty between all participants in market transactions to forgo actions based on material, nonpublic information." 20

Recognizing that this formulation posed problems for tipping cases, the court held that a tippee's liability is derivative of that of the tipper, "arising from [the tippee's] role as a participant after the fact in the insider's breach of a fiduciary duty." A tippee therefore can be held liable only when the tipper breached a fiduciary duty by disclosing information to the tippee, and the tippee knows or has reason to know of the breach of duty.

What Dirks proscribes thus is not merely a breach of confidentiality by the insider, but rather the breach of a fiduciary duty of loyalty to refrain from profiting on information entrusted to the tipper. Looking at objective criteria, courts must determine whether the insider-tipper personally benefited, directly or indirectly, from his disclosure. The most obvious case is the quid pro quo setting, in which the tipper gets some form of pecuniary gain. Non-pecuniary gain can also qualify, however. Suppose a corporate CEO discloses information to a wealthy investor not for any legitimate corporate purpose, but solely to enhance his own reputation. Dirks would find a personal benefit on those facts. Finally, Dirks indicated that liability could be imposed where the tip is a gift, because it is analogous to the situation in which the tipper trades on the basis of the information and then gives the tippee the profits.

Because Dirks requires that the tipper receive some personal benefit, it did not prohibit corporate insiders from selectively disclosing information to certain analysts so long as there was a corporate purpose for doing so. In 2000, the SEC adopted Regulation FD to create a non-insider trading-based mechanism for restricting selective disclosure. If someone acting on behalf of a public corporation discloses material nonpublic information to securities market professionals or "holders of the issuer's securities who may well trade on the basis of the information," the issuer must also disclose that information to the public. ${ }^{21}$ Where the issuer intentionally provides such disclosure, it must simultaneously

\footnotetext{
463 U.S. 646 (1983).

Id. at $654-55$.

21 Exchange Act Rel. No43,154 (Aug. 15, 2000).
} 
disclose the information in a manner designed to convey it to the general public. Hence, for example, if the issuer holds a briefing for selected analysts, it must simultaneously announce the same information through, say, a press release to "a widely disseminated news or wire service." 22 The SEC encouraged issuers to make use of the Internet and other new information technologies, such as by webcasting conference calls with analysts. Where the disclosure was not intentional, as where a corporate officer "let something slip," the issuer must make public disclosure "promptly" after a senior officer learns of the disclosure. ${ }^{23}$

In this volume, Jill Fisch traces the development of the SEC's use of Regulation FD to address information asymmetry in the securities markets. She describes the SEC's enforcement policy and notes, in particular the SEC's efforts, through its selection and settlement of Regulation FD cases, to provide guidance to corporations and corporate officials about areas of key concern. Fisch concludes by highlighting current areas of particular importance, including disclosure of information through private meetings and the implications of technological innovations such as the Internet and social media.

\section{The Misappropriation Theory and Rule 14e-3}

Dirks did not resolve the significant question posed by Chiarella; namely, to what extent does the insider trading prohibition apply where the defendant traded on the basis of market information derived from sources other than the issuer? The classic case is where an insider of a takeover bidder trades in stock of the target company on the basis of information about the bidder's plans. Such a person is not one in whom the shareholders of the target have placed their trust and confidence. Accordingly, under Chiarella no liability should arise.

\section{Rule 14e-3}

Rule $14 \mathrm{e}-3$ prohibits insiders of the bidder and target from divulging confidential information about a tender offer to persons that are likely to violate the rule by trading on the basis of that information. This provision (Rule 14e-3(d)(1)) does not prohibit the bidder from buying target shares or from telling its legal and financial advisers about its plans. Instead, it prohibits tipping of information to persons who are likely to buy target shares for their own account. Rule 14e-3 also, with certain narrow and well-defined exceptions, prohibits any person that possesses material information relating to a tender offer by another person from trading in target company securities if the bidder has commenced or has taken substantial steps towards commencement of the bid.

Unlike both the disclose or abstain rule and the misappropriation theory under Rule $10 \mathrm{~b}-5$, Rule $14 \mathrm{e}-3$ liability is not premised on breach of a fiduciary duty. There is no need for a showing that the trading party or tipper was subject to any duty of confidentiality, and no need to show that a tipper personally benefited from the tip.

22 Id.

23 Id. 


\section{Research handbook on insider trading}

\section{Misappropriation}

In response to the setbacks it suffered in Chiarella and Dirks, the SEC began advocating a new theory of insider trading liability: the misappropriation theory. Unlike Rule 14e-3, the SEC did not intend for the misappropriation theory to be limited to tender offer cases (although many misappropriation decisions have in fact involved takeovers). Accordingly, the Commission posited misappropriation as a new theory of liability under Rule 10b-5.

In US v. O'Hagan, ${ }^{24}$ the Supreme Court endorsed the misappropriation theory as a valid basis for insider trading liability. A fiduciary's undisclosed use of information belonging to his principal, without disclosure of such use to the principal, for personal gain constitutes fraud in connection with the purchase or sale of a security and thus violates Rule 10b-5.

The court acknowledged that misappropriators have no disclosure obligation running to the persons with whom they trade. Instead, it grounded liability under the misappropriation theory on deception of the source of the information: the theory addresses the use of "confidential information for securities trading purposes, in breach of a duty owed to the source of the information." ${ }^{25}$ Under this theory, "a fiduciary's undisclosed, self serving use of a principal's information to purchase or sell securities, in breach of a duty of loyalty and confidentiality, defrauds the principal of the exclusive use of that information." "26 So defined, the majority held, the misappropriation theory satisfies $\S 10($ b)'s requirement that there be a "deceptive device or contrivance" used "in connection with" a securities transaction.

\section{KEY ELEMENTS OF THE MODERN PROHIBITION}

\section{A. Inside versus Market Information}

Nonpublic information, for purposes of Rule 10b-5, takes two principal forms: "inside information" and "market information." Inside information typically comes from internal corporate sources and involves events or developments affecting the issuer's assets or earnings. Market information typically originates from sources other than the issuer and involves events or circumstances concerning or affecting the price or market for the issuer's securities and does not concern the issuer's assets or earning power. Under US law, the use of either sort is prohibited.

\section{B. Materiality}

Liability arises only with respect to trading on the basis of material information. Materiality is defined for this purpose as whether there is a substantial likelihood that a reasonable investor would consider the omitted fact important in deciding whether to buy or sell securities. ${ }^{27}$

\footnotetext{
521 U.S. 642 (1997).

Id. at 652 .

Id.

27 Basic Inc. v. Levinson, 485 U.S. 224, 231-32 (1988).
} 


\section{Nonpublic Information: When can Insiders Trade?}

Insiders may not trade whenever they are in possession of material nonpublic information. When the information in question is disclosed, insiders may trade but only after the information in question has been effectively made public. The information must have been widely disseminated and public investors must have an opportunity to act on it. At a minimum, insiders therefore must wait until the news could reasonably be expected to appear over the major business news wire services.

\section{The Requisite Fiduciary Relationship}

In neither Chiarella nor Dirks did Justice Powell lay out a convincing doctrinal basis for premising insider trading liability on a fiduciary relationship. His sole direct reference to precedent merely opined that:

In the seminal case of In re Cady, Roberts \& Co., the SEC recognized that the common law in some jurisdictions imposes on "corporate 'insiders,' particularly officers, directors, or controlling shareholders" an "affirmative duty of disclosure ... when dealing in securities." The SEC found that . . . breach of this common law duty also establish[ed] the elements of a Rule 10b-5 violation $\ldots . .^{28}$

While Justice Powell's opinion acknowledged that this common-law duty exists only in "some jurisdictions," he went on-without any explanation or citation of authority- to extrapolate therefrom a rule that all "insiders [are] forbidden by their fiduciary relationship from personally using undisclosed corporate information to their advantage." 29

Even setting aside the question of how a duty recognized only by "some" states, which historically had not applied to impersonal stock market transactions, suddenly morphed into a national insider trading ban, this formulation posed many difficult questions. For example, did one look to state or federal law to determine whether a particular relationship qualified as fiduciary in nature? The latter answer is suggested by Powell's observation "that '[a] significant purpose of the Exchange Act was to eliminate the idea that use of inside information for personal advantage was a normal emolument of corporate office." "30 Justice Powell's repeated references to a "Cady, Roberts duty" imply that Cady, Roberts created a federal duty prohibiting insider trading. If so, however, a conflict arises between the Supreme Court's insider trading precedents and its holdings on federalism elsewhere in the law of Rule 10b-5.

In Santa Fe Industries, Inc. v. Green, ${ }^{31}$ the Supreme Court held that Rule 10b-5 is concerned with disclosure and fraud, not with fiduciary duties. The court thus held, for example, that Rule 10b-5 did not reach claims "in which the essence of the complaint is that shareholders were treated unfairly by a fiduciary," ${ }^{32}$ which is the very essence of an insider trading complaint. The court justified that limitation, in part, on grounds that it

\footnotetext{
Dirks, 463 U.S. at 653.

Id. at 659 .

Id. at 653 n. 10 .

430 U.S. 462 (1977).

Id. at 477 .
} 
was reluctant "to federalize the substantial portion of the law of corporations that deals with transactions in securities, particularly where established state policies of corporate regulation would be overridden," 33 which is precisely what the federal insider trading prohibition did.

Dirks and Chiarella simply ignored this doctrinal tension. In O'Hagan, Justice Ginsburg's majority opinion tried to solve the problem by recharacterizing insider trading as a disclosure issue. It is thus the failure to disclose that one is about to inside trade that is the problem, not the trade itself. Justice Ginsburg's approach fails to solve the problem. Ginsburg accepted Powell's holdings that the duty to disclose had to arise out of a fiduciary relationship. If one is to look to federal law to determine whether a particular relationship is fiduciary in character, one is necessarily invoking the sort of "federal fiduciary standards" whose development Santa Fe clearly precludes. As a result, the conceptual conflict between the Supreme Court's current insider trading jurisprudence and its more general Rule 10b-5 precedents remains unresolved.

\section{E. State of Mind}

On its face, the connection between insider trading regulation and the state of mind of the trader or tipper seems intuitive. Insider trading is a form of market abuse: taking advantage of a secret to which one is not entitled, generally in breach of some kind of fiduciary-like duty. Donald Langevoort's chapter in this volume examines both the legal doctrine and the psychology associated with this pursuit. There is much conceptual confusion in how we define unlawful insider trading-the quixotic effort to build a coherent theory of insider trading by reference to the law of fraud, rather than a more expansive market abuse standard-which leads to interesting psychological questions as to the required state of mind. Is it always simple greed? What if there is an element of unconscious misperception - or rationalization-at work? My sense is that the causal explanations for what is charged as insider trading are sometimes quite murky and not easily explained as pure greed. Langevoort thus tries to connect the law of insider trading to a more sophisticated approach to state of mind, motivation, and causation.

\section{F. The Universe of Potential Defendants}

Who is an insider? O'Hagan confirms that the attorney-client relationship is a fiduciary one. Dictum in all three Supreme Court precedents tells us that corporate officers and directors are fiduciaries of their shareholders. Subsequent cases make clear that the universe of potential defendants is far more expansive, however.

\section{Insiders}

Exchange Act $\S 16(\mathrm{~b})$ 's short-swing profit provisions apply only to officers, directors, and shareholders owning more than 10 percent of the company's stock. One of the many issues first addressed in the seminal Texas Gulf Sulphur case was whether $\S 10$ (b) was

33 Id. at 479. 
restricted to that class of persons. The court had little difficulty finding that mid-level corporate employees were insiders for purposes of Rule 10b-5. "Insiders, as directors or management officers are, of course, by this Rule, precluded from [insider] dealing, but the Rule is also applicable to one possessing [nonpublic] information who may not be strictly termed an 'insider' within the meaning of [section] 16(b) of the Act." ${ }^{34}$ Although Chiarella's rejection of Texas Gulf Sulphur's equal access test shrank the universe of potential defendants substantially, the court's reference to an "agent" of the issuing corporation as a proper defendant confirmed that the Rule encompassed all corporate employees, rather than just $\S 16(b)$ insiders.

\section{Constructive insiders}

Not all of a corporation's agents are employees, of course. Accordingly, in Dirks, Justice Powell held that certain outsiders' relationship with the issuer qualifies as fiduciary for purposes of the insider trading prohibition:

Under certain circumstances, such as where corporate information is revealed legitimately to an underwriter, accountant, lawyer, or consultant working for the corporation, these outsiders may become fiduciaries of the shareholders. The basis for recognizing this fiduciary duty is not simply that such persons acquired nonpublic corporate information, but rather that they have entered into a special confidential relationship in the conduct of the business of the enterprise and are given access to information solely for corporate purposes .... For such a duty to be imposed, however, the corporation must expect the outsider to keep the disclosed nonpublic information confidential, and the relationship at least must imply such a duty. ${ }^{35}$

Although Dirks clearly requires that the recipient of the information in some way agree to keep it confidential, courts have sometimes overlooked that requirement. In SEC v. Lund, ${ }^{36}$ for example, Lund and another businessman discussed a proposed joint venture between their respective companies. In those discussions, Lund received confidential information about the other's firm. Lund thereafter bought stock in the other's company. The court determined that by virtue of their close personal and professional relationship, and because of the business context of the discussion, Lund was a constructive insider of the issuer. In doing so, however, the court focused almost solely on the issuer's expectation of confidentiality. It failed to inquire into whether Lund had agreed to keep the information confidential. A subsequent case from the same district court acknowledged that this was an error:

What the Court seems to be saying in Lund is that anytime a person is given information by an issuer with an expectation of confidentiality or limited use, he becomes an insider of the issuer. But under Dirks, that is not enough; the individual must have expressly or impliedly entered into a fiduciary relationship with the issuer. ${ }^{37}$

Even this statement does not go far enough, however, because it does not acknowledge the additional requirement of an affirmative assumption of the duty of confidentiality.

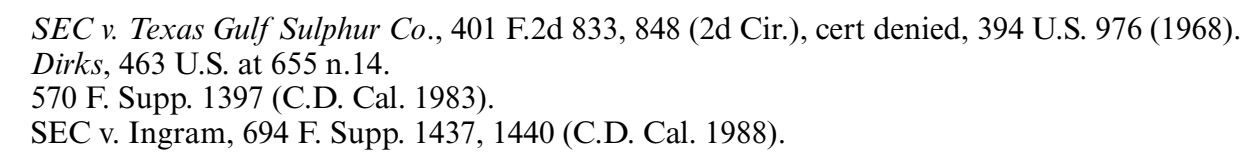




\section{Research handbook on insider trading}

\section{Tippers and tippees}

Dirks held that tippees could be held liable, provided two conditions are met: (1) the tipper breached a fiduciary duty to the corporation by making the tip; and (2) the tippee knew or had reason to know of the breach. The requirement that the tip constitute a breach of duty on the tipper's part eliminates many cases in which an insider discloses information to an outsider. For example, no fiduciary obligation is violated by making disclosures for a legitimate corporate purpose.

Indeed, not every disclosure made in violation of a fiduciary duty constitutes an illegal tip. What Dirks proscribes is not just a breach of duty, but a breach of the duty of loyalty forbidding fiduciaries to personally benefit from the disclosure. Hence, for example, negligently discussing business confidences in a public place may be careless, but it is not a breach of one's duty of loyalty and thus does not give rise to liability.

\section{Nontraditional relationships}

Outside the traditional categories of Rule 10b-5 defendants - insiders, constructive insiders, and their tippees - things become more complicated. Suppose a doctor learned confidential information from a patient, upon which she then traded? Is she an insider? As the Second Circuit observed in United States v. Chestman: ${ }^{38}$

[F]iduciary duties are circumscribed with some clarity in the context of shareholder relations but lack definition in other contexts. Tethered to the field of shareholder relations, fiduciary obligations arise within a narrow, principled sphere. The existence of fiduciary duties in other common law settings, however, is anything but clear. Our Rule 10b-5 precedents ..., moreover, provide little guidance with respect to the question of fiduciary breach, because they involved egregious fiduciary breaches arising solely in the context of employer/employee associations. ${ }^{39}$

In Chestman, the question was whether the relationship between spouses was fiduciary in nature. In answering that question, the court laid out a general framework for dealing with nontraditional relationships. First, unilaterally entrusting someone with confidential information does not by itself create a fiduciary relationship. ${ }^{40}$ This is true even if the disclosure is accompanied by an admonition such as "don't tell." Secondly, familial relationships are not fiduciary in nature without some additional element.

Turning to factors that could justify finding a fiduciary relationship on these facts, the court first identified a list of "inherently fiduciary" associations. "Counted among these hornbook fiduciary relations are those existing between attorney and client, executor and heir, guardian and ward, principal and agent, trustee and trust beneficiary, and senior corporate official and shareholder." 41 Once one moves beyond these "hornbook" fiduciary relationships, the requisite relationship exists where one party acts on the other's behalf and "great trust and confidence" exists between the parties:

8947 F.2d 551 (2d Cir. 1991) (citations omitted), cert. denied, 503 U.S. 1004 (1992).

39 Id. at 567.

40 Repeated disclosures of business secrets, however, could substitute for a factual finding of dependence and influence and, accordingly, sustain a finding that a fiduciary relationship existed in the case at bar. Id. at 569 .

41 Id. at 568. 
A fiduciary relationship involves discretionary authority and dependency: One person depends on another - the fiduciary - to serve his interests. In relying on a fiduciary to act for his benefit, the beneficiary of the relation may entrust the fiduciary with custody over property of one sort or another. Because the fiduciary obtains access to this property to serve the ends of the fiduciary relationship, he becomes duty-bound not to appropriate the property for his own use. ${ }^{42}$

Because the spousal relationship did not involve either discretionary authority or dependency of this sort, it was not fiduciary in character.

In 2000, the SEC addressed the Chestman issue by adopting Rule 10b5-2, which provides "a nonexclusive list of three situations in which a person has a duty of trust or confidence for purposes of the 'misappropriation' theory ...." First, such a duty exists whenever someone agrees to maintain information in confidence. Secondly, such a duty exists between two people who have a pattern or practice of sharing confidences such that the recipient of the information knows, or reasonably should know, that the speaker expects the recipient to maintain the information's confidentiality. Thirdly, such a duty exists when someone receives or obtains material nonpublic information from a spouse, parent, child, or sibling. On the facts of Chestman, accordingly, Rule 10b5-2 would result in the imposition of liability because Keith received the information from his spouse who, in turn, had received it from her parent. The validity of this expansion of liability from fiduciary relationships to those based purely on contract remains unresolved.

\section{Legislators}

A sharp controversy the US insider trading laws applied to a special class of nontraditional defendants erupted when a study found evidence of insider trading by members of the US Congress. Over time, nobody beats the market. This basic premise of efficient capital markets theory has been confirmed in numerous academic studies. ${ }^{43}$ The only important exception to the rule traditionally has been corporate insiders trading in their own corporation's stock. ${ }^{44}$ The obvious and generally accepted explanation for insiders' results is their access to and use of material nonpublic information about the company. ${ }^{45}$

A 2004 study of the results of stock trading by US Senators during the 1990s, however, found that Senators on average beat the market by 12 percent a year. ${ }^{46}$ In sharp contrast, US households on average underperformed the market by 1.4 percent a year and even corporate insiders on average beat the market by only about 6 percent a year during that period. ${ }^{47}$ A reasonable inference is that some Senators had access to - and were usingmaterial nonpublic information about the companies in whose stock they trade:

\footnotetext{
42 Id. at 569.

43 Bob Ryan, Corporation Finance and Valuation 84 (2006) ("The empirical evidence is absolutely solid, fund managers cannot out perform the market ....").

44 Hasan Nejat Seyhun, Investment Intelligence From Insider Trading 312 (2000).

45 Id. at 74.

46 Alan J. Ziobrowski et al., Abnormal Returns from the Common Stock Investments of the U.S. Senate, 39 J. Fin. \& Quant. Anal. 661 (2004).

47 Jane J. Kim, U.S. Senators' Stock Picks Outperform the Pro's, Wall. St. J., Oct. 26, 2004, available at http://tinyurl.com/nrwm6r.
} 


\section{Research handbook on insider trading}

Looking at the timing of cumulative returns, the senators also appeared to know exactly when to buy or sell their holdings. Senators would buy stocks just before the shares suddenly would outperform the market by more than $25 \%$. Conversely, senators would sell stocks that had been beating the market by about $25 \%$ for the past year just when the shares would fall back in line with the market's performance.

The researchers say senators' uncanny ability to know when to buy or sell their shares seems to stem from having access to information that other investors wouldn't have. "I don't think you need much of an imagination to realize that they're in the know," says Alan Ziobrowski, a business professor at Georgia State University in Atlanta and one of the four authors of the study. ${ }^{48}$

Members of Congress can obtain material nonpublic information in many ways. They can learn inside information when, for example, a company confidentially discloses it during the course of a Congressional hearing or investigation. In most cases, however, members of Congress likely trade on the basis of market information. "Market information' refers to information that affects the price of a company's securities without affecting the firm's earning power or assets. . . Examples include information that an investment adviser will shortly issue a 'buy' recommendation or that a large stockholder is seeking to unload his shares or that a tender offer will soon be made for the company's stock." ${ }^{49}$ In the present context, examples of market information readily available to members of Congress include knowing that "tax legislation is apt to pass and which companies might benefit," being aware "that a particular company soon will be awarded a government contract or that a certain drug might get regulatory approval . .." ${ }^{50}$

Commentators disagreed as to whether insider trading by members of Congress was captured by existing US insider trading laws. ${ }^{51}$ In this volume, Sung Hui Kim revisits the issue. Specifically, she explores a curious distinction that Henry G. Manne made in his influential 1966 book, Insider Trading And The Stock Market. On the one hand, Manne defended corporate insider trading because of its potential to increase share price accuracy and its usefulness as a compensation tool for entrepreneurial innovations. On the other hand, Manne denounced the practice of governmental insider trading, seeing no good reason to compensate government officials on the side and warning against "the ease with which inside information can be utilized as a payoff device." Kim argues that such a bifurcated position is unstable. She contends that, just as governmental insider trading should be viewed as a form of public corruption, corporate insider trading should be viewed as a form of corruption in the private sector. Moreover, she argues that if one examines the reasons why public corruption in the form of governmental insider trading

\footnotetext{
48 Id. The extent of Congressional trading on material nonpublic information is uncertain. "Just over a third of the senators bought or sold individual stocks in any one year in the study, and the vast majority of stock transactions were less than $\$ 15,000$." Id.

49 U.S. v. Chiarella, 588 F.2d 1358, 1365 n.8 (2d Cir. 1978), rev'd on other grounds, 445 U.S. 222 (1980).

50 Kim, supra note 47.

51 Compare Stephen M. Bainbridge, Insider Trading Inside the Beltway, 36 J. Corp. L. 281, 285 (2011) ("Congressional staffers and other government officials and employees could be prosecuted successfully for insider trading under the federal securities laws, but the quirks of the relevant laws almost certainly would prevent Members of Congress from being successfully prosecuted"), with Donna M. Nagy, Insider Trading, Congressional Officials, and Duties of Entrustment, 91 B.U. L. Rev. 1105 (2011) (arguing to the contrary).
} 
is normatively problematic, one sees that similar reasons apply to private corruption in the form of corporate insider trading. Thus, if one rejects governmental insider trading, one has good reason to reject corporate insider trading as well.

J.W. Verret's chapter explores the related issue of trading on the basis of political intelligence. Verret examines the Stop Trading on Congressional Knowledge Act (STOCK Act), which was adopted in the USA in 2012 in response to the allegations discussed above of insider trading by members of Congress on the basis of nonpublic information obtained through their elected position. Verret offers a critique of the STOCK Act, demonstrating three key flaws. ${ }^{52}$ The STOCK Act grafts a fiduciary duty relationship created in a distinctly different context, corporate law, into the relationship between Congress and the taxpayer in a way that makes enforcement of the Act potentially either under-inclusive or over-inclusive of the behavior the Act's drafters sought to prevent. He demonstrates how these problems also apply to the Act's application to government employees. Verret also shows how the Act's reference to existing law under Section 10b-5 will introduce a raft of uncertainty as doctrines developed therein, such as the misappropriation doctrine, extend the reach of the Act to outsiders, like political intelligence traders, that the Act ostensibly sought to exclude.

\section{G. Recent Developments}

Stephen Diamond's chapter in this volume discusses the dismissal of a senior Facebook employee in connection with the purchase of Facebook shares on a private resale trading platform prior to the Facebook IPO, which raised new concerns about secondary trading in the securities of private companies and insider trading. After exploring those issues, Diamond suggests that startup companies consider adopting a variation on the standard insider trading policy widely adopted by public companies. The case study is especially important in light of new attention being paid by regulators to insider trading as well as an ongoing debate in Congress about barriers to raising capital for smaller companies. Joan Heminway's chapter describes the interrelationship between gender and US insider trading law and explores (anecdotally and through extensions of existing gender studies outside the insider trading realm) the potential roles and significance of gender in that context. Although women have become more visible as participants in the securities markets and as alleged and actual transgressors of insider trading rules, the role of gender and women in insider trading is still poorly understood, except anecdotally. Accordingly, Heminway argues, the portrait of the insider trader as a woman is a work in progress to which targeted research can make significant contributions.

Volume editor Stephen Bainbridge's chapter argues that the narrowing of the scope of insider trading liability effect by the Supreme Court's decisions in Chiarella and Dirks met substantial resistance from the SEC and the lower federal courts. Through both regulatory actions and judicial opinions, the SEC and the lower courts gradually chipped away at the

${ }^{52}$ Kim's chapter also discusses the STOCK Act, but her analysis deliberately extends beyond trading by members of Congress to consider the liability of state legislators and the relationships between Congressional and private insider trading from a policy perspective. 
fiduciary duty rationale. In recent years, moreover, the trend has accelerated, with several developments having substantially eviscerated the fiduciary duty requirement. After tracing those developments, Bainbridge argues that the current unsettled state of insider trading jurisprudence necessitates rethinking the foundational premises of that jurisprudence from first principles. He argues that the correct rationale for regulation insider trading is protecting property rights in information. Although that rationale obviously has little to do with the traditional concerns of securities regulation, he further argues that the SEC has a sufficiently substantial competitive advantage over private parties and state enforcers in detecting and prosecuting insider trading that it should retain jurisdiction over the offense.

\section{GLOBALIZATION OF INSIDER TRADING LAW}

Today, all countries with developed capital markets limit insider trading to some extent. In many respects, however, this is a relatively recent phenomenon. A generation ago, the United States was virtually alone in aggressively prosecuting insider trading and even today US insider trading law remains the most restrictive legal regime. Global restrictions on the practice thus have largely come about as other jurisdictions converge on the US model. In this volume, a number of contributors focus on insider trading laws in key securities markets around the world. ${ }^{53}$

\section{A. Australasia}

Keith Kendall and Gordon Walker's chapter in this volume traces the evolution of the present insider trading regime in Australia, highlighting some contentious issues with that regime and noting the aggressive enforcement of insider trading laws in that country. Australia was the first jurisdiction in the world to eliminate the requirement for a connection - fiduciary, contractual, or otherwise - with the subject company. Since the 1990s, Australia has prohibited "any person" from trading on inside information regardless of any connection with the subject company. Thus, Australia can be regarded as the most longstanding of those jurisdictions - others being Singapore, Malaysia, and New Zealand-that have adopted the "any person" regime.

The insider trading laws of one of those jurisdictions-i.e., New Zealand-are described and analyzed by Gordon Walker and Andrew Simpson's chapter. New Zealand's first comprehensive statutory regime banning insider trading was introduced in 1988. This regime, as amended, persisted until 2008. Generally speaking, the 1988-2008 laws on insider trading in New Zealand are regarded as a failure due to the initial absence of enforcement power by the regulator and poor design. In 2008, New Zealand adopted a version of Australian insider trading laws pursuant to which "any person" in possession of inside information is prohibited from trading. Walker and Simpson review the 1988-2008 regime and then outline the statutory prohibitions applying since 2008 . They

53 At the risk of semantic confusion, the term "insider dealing" is used in this volume in lieu of the US term "insider trading" when preferred by authors writing about non-US jurisdictions. 
conclude by noting the absence of any prosecutions under the present regime and suggest some reasons for this phenomenon.

\section{B. China}

Nicholas Howson's contribution to this volume presents a general introduction to the current law and regulation of insider trading in the People's Republic of China, and the reality of enforcement against insider trading in China's domestic capital markets. His analysis focuses on the extremely broad scope of insider trading liability created under nonpublic "guidance" formulated by the Chinese securities regulator, which guidance departs significantly from the more narrowly drawn insider trading prohibition established in China's 2006 Securities Law. Although the statute establishes a combination of the classical/fiduciary duty plus misappropriation theories for liability, the agency guidance - both formally and in application - results in liability for those trading while merely in possession of inside information.

Hui Huang's chapter also provides an in-depth and updated analysis of insider trading regulation in China, looking at both the law "in the books" and "in action." Beginning in the early 1990s, China has gradually set up a regulatory regime for insider trading in line with international experiences. Twenty years on, Huang examines the effectiveness of China's insider trading regime. He critically examines the key elements of insider trading law, as well as its theoretical basis in light of recent cases, from a comparative perspective. He then reports the results of an empirical study of China's insider trading cases to provide insight into public and private enforcement of the law, and, based on the findings, makes relevant suggestions to improve the efficacy of insider trading regulation in China.

\section{Europe}

Kern Alexander's chapter analyzes UK law governing insider trading and how it has evolved in recent years. Although the substantive law has generally remained the same, UK authorities are increasing investigations and enforcement to counter the reputation of the City of London as a rather "light touch" jurisdiction that has tolerated market misconduct. Insider dealing is a criminal offense defined under Part V of the Criminal Justice Act 1993. In contrast, market abuse is a civil offense as set forth in sections 118-123 of the Financial Services and Markets Act 2000. Alexander reviews the UK insider dealing law and analyzes some related issues concerning the difficulty and complexity of its application. He then discusses the UK market abuse offense and its development under the EU Directive on Insider Dealing and Market Manipulation. His final section discusses recent efforts by the UK Financial Services Authority to increase investigations and enforcement and to develop a more proactive posture in dealing with market misconduct in UK financial markets.

Katja Langenbucher's chapter provides an overview of EU insider trading law, which thus far consists of one core and two implementing directives, with proposals for a regulation and a directive pending. The European Court of Justice has heard three cases on insider trading law, while a fourth was pending at the time of writing. In discussing these laws and cases, Langenbucher argues that European law views insider trading as a form of market abuse that hinders prompt disclosure. This approach is reflected in the Directive's 
technical setup, as the existence of inside information automatically triggers both a prohibition on insider trading and a disclosure requirement.

Matthijs Nelemans and Michael Schouten's chapter analyzes the European regulatory framework with respect to insider trading in the context of takeover bids. They distinguish between trading by the bidder, by the target, and by classical insiders such as officers and employees, and where relevant compare EU law with US federal securities laws. First, they address the issue of precisely when information about potential takeover bids qualifies as inside information. Secondly, they address the prohibition on selectively sharing inside information with third parties, the prohibition on tipping, and the obligation to make public disclosure. Thirdly, they analyze the extent to which bidders are permitted to build a stake in the target prior to announcement of the offer. In connection therewith, Nelemans and Schouten also discuss the prohibition of target companies and classical insiders to trade on information regarding a pending offer. Finally, they discuss reporting obligations in respect of inside trades. Their analysis suggests that European insider trading laws are insufficiently tailored for corporations, and that significant uncertainty remains as to the precise scope of the prohibition on insider trading in the context of takeover bids.

\section{Japan}

Mark Ramseyer's contribution to this volume begins by explaining that, following World War II, the US-controlled occupation authority imposed an American-style securities statute on Japan. The US statute did not ban insider trading at the time, so neither did the new Japanese law. When the US courts developed the prohibition of insider trading in the 1960s, Japanese regulators and courts did not follow their lead. As late as the mid-1980s, Japan thus had left insider trading largely unregulated.

In 1988, the Japanese Diet adopted a statute that banned and criminalized insider trading. Rather than use a vague rule like the US's Rule 10b-5, the Japanese law carefully specified which investors, which trades, and which contexts would trigger the ban. In 2004, it added an administrative surcharge regime. Commentators in Japan ostensibly urged the Diet to adopt the bill because they hoped to restore investor confidence in the stock market. If the ban restored investor confidence, it did not show. Shortly after the ban took effect, the Japanese stock market collapsed.

\section{EMPIRICAL RESEARCH}

In this volume, Laura Beny and Nejat Seyhun investigate whether the increase in enforcement actions against insider trading by the SEC and the Department of Justice in recent years is a response to increased illegal insider trading activity. They examine the pricing of common stocks and options around the announcement of tender offers to detect the presence of illegal insider trading, so as to determine whether illegal insider trading occurs before tender offers and whether illegal insider trading has become more rampant over time. Their findings suggest that the pre-takeover announcement run-up in stock prices has become larger over time. During the 2006-2011 sub-period, the pre-bid run-up was 50 percent higher than in the pre-2006 period. They also find that toehold investments by 
bidders do not explain the time-series variation in stock price behavior around takeovers. In contrast, the increases in the implied volatility of the options on target stock they find are consistent with increasing illegal insider trading.

Laura Beny's solo chapter uses data from a cross-section of countries between 1980 and 1999 to find that a country's political system - not its legal or financial system - best explains its proclivity to regulate insider trading. Specifically, more democratic nations enacted and enforced insider trading laws earlier than less democratic nations, controlling for wealth, financial development, legal origin, and other factors. Furthermore, controlling for the same factors, left-leaning governments were latecomers to insider trading legislation and enforcement relative to right-leaning and centrist governments.

According to Beny, these results are generally consistent with the political theory of capital market development and inconsistent with the legal origins theory of capital market development. They also challenge theoretical claims that insider trading restrictions are market-inhibiting because the kinds of governments that appear more inclined to regulate insider trading are precisely the governments that are generally thought to pursue market-promoting policies.

Alexandre Padilla's chapter offers a critique of the broader empirical literature about the effects of insider trading laws on capital markets. He argues that while the literature shows that, statistically, insider trading laws positively affect capital market development, this correlation does not actually prove that insider trading is harmful to markets. In addition, he argues that many of the benefits of insider trading laws might translate in the long run into costs resulting in more shareholders' expropriation. Building on Hayek's work on understanding the role of the price system as a mechanism to economize on information and, more particularly, on local knowledge, he argues that allowing insider trading could under certain circumstances reduce shareholders' expropriation on the part of corporate management. Finally, Padilla suggests possible new lines of empirical research to address the questions raised in the chapter.

\section{THE POLICY DEBATE}

Insider trading's modern normative jurisprudence began with the 1966 publication of Henry Manne's Insider Trading And The Stock Market. Manne contended that insider trading promotes market efficiency and creates efficient incentives for innovative corporate managers. In reply, defenders of an insider trading ban typically have relied either on fairness arguments or claims that insider trading has substantial economic costs.

\section{A. The Case for Deregulation}

Manne identified two principal ways in which insider trading benefits society and/or the firm in whose stock the insider traded. First, he argued that insider trading causes the market price of the affected security to move towards the price that the security would command if the inside information were publicly available. If this is so, both society and the firm benefit through increased price accuracy. Secondly, he posited insider trading 
as an efficient way of compensating managers for having produced information. If this is so, the firm benefits directly (and society indirectly) because managers have a greater incentive to produce additional information of value to the firm.

\section{Insider trading and efficient pricing of securities}

Although US securities laws purportedly encourage accurate pricing by requiring disclosure of corporate information, they do not require the disclosure of all material information. Where disclosure would interfere with legitimate business transactions, disclosure by the corporation is usually not required unless the firm is dealing in its own securities at the time. When a firm withholds material information, however, the market can no longer accurately price its securities.

Manne essentially argued that insider trading is an effective compromise between the need for preserving incentives to produce information and the need for maintaining accurate securities prices. Suppose a firm, the stock of which currently sells at fifty dollars per share, has discovered new information that, if publicly disclosed, would cause the stock to sell at sixty dollars. Absent insider trading or leaks, the stock's price will remain at fifty dollars until the information is publicly disclosed and then rapidly rise to the correct price of sixty dollars. If insiders trade on this information, however, the price of the stock will gradually rise towards the correct price. Thus, insider trading acts as a replacement for public disclosure of the information, preserving market gains of correct pricing while permitting the corporation to retain the benefits of nondisclosure. ${ }^{54}$

Despite the anecdotal support for Manne's position provided by Texas Gulf Sulphur and similar cases, empirical evidence on the point remains scanty. Early market studies indicated insider trading had an insignificant effect on price in most cases. ${ }^{55}$ Subsequent studies suggested the market reacts fairly quickly when insiders buy securities, but the initial price effect is small when insiders sell. ${ }^{56}$ These studies are problematic, however, because they relied principally (or solely) on the transactions reports corporate officers, directors, and 10 percent shareholders are required to file under Section 16(a). Because insiders are unlikely to report transactions that violate Rule 10b-5, and because much illegal insider trading activity is known to involve persons not subject to the $\S 16$ (a) reporting requirement, conclusions drawn from such studies may not tell us very much about the price and volume effects of illegal insider trading. Accordingly, it is significant that a study of SEC insider trading cases found that the defendants' insider trading led to quick price changes. ${ }^{57}$ That result supports Manne's empirical claim, subject to the caveat that reliance on data obtained from SEC prosecutions arguably may not be conclusive as to the price effects of undetected insider trading due to selection bias, although the study in question admittedly made strenuous efforts to avoid any such bias.

Turning to theory, the anonymity of impersonal market transactions makes it far

\footnotetext{
54 Henry Manne, Insider Trading And The Stock Market 77-91 (1966).

55 See Roy A. Schotland, Unsafe at Any Price, 53 Va. L. Rev. 1425, 1443 (1967) (citing studies).

56 Dan Givoly \& Dan Palmon, Insider Trading and the Exploitation of Inside Information: Some Empirical Evidence, 58 J. Bus. 69 (1985).

57 Lisa Meulbrock, An Empirical Analysis of Illegal Insider Trading, 47 J. Fin. 1661 (1992).
} 
from obvious that insider trading will have any effect on prices. Suppose an insider buys stock on good news. The supply of stock remains constant (assuming the company is not in the midst of a stock offering or repurchase), but demand has increased, so a higher equilibrium price should result. Because a given security represents only a particular combination of expected return and systematic risk, for which there is a vast number of substitutes, the correct measure for the supply of securities thus is not simply the total of the firm's outstanding securities, but the vastly larger number of securities with a similar combination of risk and return. Accordingly, the supply/demand effect of a relatively small number of insider trades should not have a significant price effect. Over the portion of the curve observed by individual traders, the demand curve should be flat rather than downward sloping.

Instead, if insider trading is to affect the price of securities it is through the derivatively informed trading mechanism of market efficiency. Derivatively informed trading affects market prices through a two-step mechanism. First, those individuals possessing material nonpublic information begin trading. Their trading has only a small effect on price. Some uninformed traders become aware of the insider trading through leakage or tipping of information or through observation of insider trades. Other traders gain insight by following the price fluctuations of the securities. Finally, the market reacts to the insiders' trades and gradually moves towards the correct price. The problem is that while derivatively informed trading can affect price, it functions slowly and sporadically. Given the inefficiency of derivatively informed trading, many observers doubt whether market efficiency provides a robust justification for allowing insider trading.

Having said that, however, in this volume Alexandre Padilla offers a critique of the empirical literature on the effects insider trading laws have on capital markets. He argues that many of the purported benefits of regulating insider trading put forward by proponents of the prohibition are actually harmful for markets. His chapter argues that, although the literature shows that there is a statistically significant correlation between insider trading laws and capital market development, this correlation does not actually prove that insider trading is harmful to markets. In addition, he argues that regulation leads to unintended consequences that might be averted if insider trading was allowed or, at least, if the decision whether to allow or ban it was left to securities markets. Building on Hayek's work on understanding the role of local knowledge in enabling an efficient price system he provides a modern version of Manne's argument that allowing insider trading will enhance the price system.

\section{Insider trading as an efficient compensation scheme}

Manne's other principal argument against the ban on insider trading rested on the claim that allowing insider trading was an effective means of compensating entrepreneurs in large corporations. Manne distinguished corporate entrepreneurs from mere corporate managers. The latter simply operate the firm according to predetermined guidelines. By contrast, an entrepreneur's contribution to the firm consists of producing new valuable information. The entrepreneur's compensation must have a reasonable relation to the value of his contribution to give him incentives to produce more information. Because it is rarely possible to ascertain information's value to the firm in advance, predetermined compensation, such as salary, is inappropriate for entrepreneurs. Instead, 
claimed Manne, insider trading is an effective way to compensate entrepreneurs for innovations. The increase in the price of the security following public disclosure provides an imperfect but comparatively accurate measure of the value of the innovation to the firm. The entrepreneur can recover the value of his discovery by purchasing the firm's securities prior to disclosure and selling them after the price rises. ${ }^{58}$

Manne argued salary and bonuses provide inadequate incentives for entrepreneurial inventiveness because they fail to accurately measure the value to the firm of innovations. Query, however, whether insider trading is any more accurate. Even assuming the change in stock price accurately measures the value of the innovation, the insider's compensation is limited by the number of shares he can purchase. This, in turn, is limited by his wealth. As such, the insider's trading returns are based, not on the value of his contribution, but on his wealth.

Another objection to the compensation argument is the difficulty of restricting trading to those who produced the information. Where information is concerned, production costs normally exceed distribution costs. As such, many firm agents may trade on the information without having contributed to its production.

A related criticism is the difficulty of limiting trading to instances in which the insider actually produced valuable information. In particular, why should insiders be permitted to trade on bad news? Allowing managers to profit from inside trading reduces the penalties associated with a project's failure because trading managers can profit whether the project succeeds or fails. If the project fails, the manager can sell his shares before that information becomes public and thus avoid an otherwise certain loss. The manager can go beyond mere loss avoidance into actual profit making by short selling the firm's stock. A final objection to the compensation thesis follows from the contingent nature of insider trading. Because the agent's trading returns cannot be measured in advance, neither can the true cost of his reward. As a result, selection of the most cost-effective compensation package is made more difficult. Moreover, the agent himself may prefer a less uncertain compensation package. If an agent is risk averse, he will prefer the certainty of a $\$ 100,000$ salary to a salary of $\$ 50,000$ and a 10 percent chance of a bonus of $\$ 500,000$ from insider trading. Thus, the shareholders and the agent would gain by exchanging a guaranteed bonus for the agent's promise not to trade on inside information.

In this volume, we are honored to have Manne contribute a chapter in which he revisits and updates the compensation argument. Manne remains concerned with using compensation to properly incentivize entrepreneurs, especially in large, publicly held corporations, where he argues discovery and unpredictable innovation indisputably take place despite the literature's fascination with startups. The puzzling question is how such firms compensate entrepreneurs. Manne reviews developments in compensation practices in the years since he first broached the subject and concludes that none have solved the basic problem of optimizing entrepreneurial incentives. Instead, he argues, they serve as second best substitutes for allowing insiders to trade on the basis of information they develop. Despite the concerns raised above, Manne thus contends that the current compensation regime is equally flawed. No system can be perfect and

58 Manne, supra note 54, at 131-41. 
insider trading offers many advantages as a way of creating firm-wide incentives to innovate.

\section{B. The Case for Regulation}

\section{Fairness}

There is a widely shared view that there is something inherently sleazy about insider trading. As a California court put it, insider trading is "a manifestation of undue greed among the already well-to-do, worthy of legislative intervention if for no other reason than to send a message of censure on behalf of the American people." 59

Given the draconian penalties associated with insider trading, however, such vague and poorly articulated notions of fairness surely provide an insufficient justification for the prohibition. Fairness can be defined in various ways. Most of these definitions, however, collapse into the various efficiency-based rationales for prohibiting insider trading. We might define fairness as fidelity, for example, by which I mean the notion that an agent should not cheat her principal. But this argument only has traction if insider trading is in fact a form of cheating, which in turn depends on how we assign the property right to confidential corporate information. Alternatively, we might define fairness as equality of access to information, as many courts and scholars have done, but this definition must be rejected in light of Chiarella's rejection of the Texas Gulf Sulphur equal access standard. Finally, we might define fairness as a prohibition of injuring another. But such a definition justifies an insider trading prohibition only if insider trading injures investors, which seems unlikely. Accordingly, fairness concerns do little to advance the case for banning insider trading.

\section{Injury to investors}

An investor who trades in a security contemporaneously with insiders having access to material nonpublic information likely will allege injury in that he sold at the wrong price; i.e., a price that does not reflect the undisclosed information. If a firm's stock currently sells at $\$ 10$ per share, but after disclosure of the new information will sell at $\$ 15$, a shareholder who sells at the current price thus will claim a \$5 loss.

The investor's claim, however, is fundamentally flawed. It is purely fortuitous that an insider was on the other side of the transaction. The gain corresponding to the shareholder's loss is reaped not just by inside traders, but by all contemporaneous purchasers whether they had access to the undisclosed information or not. ${ }^{60}$

Granted, the investor might not have sold if he had had the same information as the insider, but even so the rules governing insider trading are not the source of his problem. On an impersonal trading market, neither party knows the identity of the person with whom he is trading. Thus, the seller has made an independent decision to sell without

\footnotetext{
59 Friese v. Superior Court, 36 Cal.Rptr.3d 558, 566 (Cal. App. 2005).

${ }_{60}$ Granted, insider trading results in outside investors as a class reaping a smaller share of the gains from new information. William Wang, Trading on Material Nonpublic Information on Impersonal Stock Markets: Who Is Harmed, and Who Can Sue Whom Under SEC Rule 10b-5?, 54 S. Cal. L. Rev. 1217 (1981) (positing the "law of conservation of securities").
} 
knowing that the insider is buying; if the insider were not buying, the seller would still sell. It is thus the nondisclosure that causes the harm, rather than the mere fact of trading. ${ }^{6}{ }^{1}$

The information asymmetry between insiders and public investors arises out of the mandatory disclosure rules allowing firms to keep some information confidential even if it is material to investor decision making. Unless immediate disclosure of material information is to be required, a step the law has been unwilling to take, there will always be winners and losers in this situation. Irrespective of whether insiders are permitted to inside trade or not, the investor will not have the same access to information as the insider. It makes little sense to claim that the shareholder is injured when his shares are bought by an insider, but not when an outsider buys them without access to information. To the extent the selling shareholder is injured, his injury thus is correctly attributed to the rules allowing corporate nondisclosure of material information, not to insider trading. A more sophisticated argument is that the price effects of insider trading induce shareholders to make poorly advised transactions. It is doubtful whether insider trading produces the sort of price effects necessary to induce shareholders to trade, however. As noted earlier, while derivatively informed trading can affect price, it functions slowly and sporadically. Given the inefficiency of derivatively informed trading, price or volume changes resulting from insider trading will only rarely be of sufficient magnitude to induce investors to trade.

Assuming for the sake of argument that insider trading produces noticeable price effects, however, and further assuming that those effects mislead some investors, the inducement argument remains flawed because many transactions would have taken place regardless of the price changes resulting from insider trading. Investors, who would have traded irrespective of the presence of insiders in the market, benefit from insider trading because they transacted at a price closer to the correct price; i.e., the price that would prevail if the information were disclosed. In any case, it is hard to tell how the inducement argument plays out when investors are examined as a class. For any given number who decide to sell because of a price rise, for example, another group of investors may decide to defer a planned sale in anticipation of further increases.

An argument closely related to the investor injury issue is the claim that insider trading undermines investor confidence in the securities market. In the absence of a credible investor injury story, it is difficult to see why insider trading should undermine investor confidence in the integrity of the securities markets.

In sum, neither investor protection nor maintenance of confidence have much traction as theoretical justifications for any prohibition of insider trading. Nor do they have much explanatory power with respect to the prohibition currently on the books. An investor's rights vary widely depending on the nature of the insider trading transaction, the identity of the trader, and the source of the information. Yet, if the goal is investor protection, why should these considerations be relevant?

Recall, for example, United States v. Carpenter. ${ }^{62}$ R. Foster Winans wrote the Wall

61 On an impersonal exchange, moreover, the precise identity of the seller is purely fortuitous and it is difficult to argue that the seller who happened to be matched with the insider has been hurt more than any other contemporaneous seller whose sale was not so matched.

62 United States v. Carpenter, 791 F.2d 1024, 1026-27 (2d Cir. 1986), aff'd, 484 U.S. 19 (1987). 
Street Journal's "Heard on the Street" column, a daily report on various stocks that is said to affect the price of the stocks discussed. Journal policy expressly treated the column's contents prior to publication as confidential information belonging to the newspaper. Despite that rule, Winans agreed to provide several co-conspirators with prepublication information as to the timing and contents of future columns. His fellow conspirators then traded in those stocks based on the expected impact of the column on the stocks' prices, sharing the profits. In affirming their convictions, the Second Circuit anticipated O'Hagan by holding that Winans's breach of his fiduciary duty to the Wall Street Journal satisfied the standards laid down in Chiarella and Dirks. From either an investor protection or confidence in the market perspective, however, this outcome seems bizarre at best. For example, any duties Winans owed in this situation ran to an entity that had neither issued the securities in question nor even participated in stock market transactions. What Winans's breach of his duties to the Wall Street Journal has to do with the federal securities laws, if anything, is not self-evident.

The incongruity of the misappropriation theory becomes even more apparent when one considers that its logic suggests that the Wall Street Journal could lawfully trade on the same information used by Winans. If we are really concerned with protecting investors and maintaining their confidence in the market's integrity, the inside trader's identity ought to be irrelevant. From the investors' point of view, insider trading is a matter of concern only because they have traded with someone who used their superior access to information to profit at the investors' expense. As such, it would not appear to matter whether it is Winans or the Journal on the opposite side of the transaction. Both have greater access to the relevant information than do investors.

The logic of the misappropriation theory also suggests that Winans would not have been liable if the Wall Street Journal had authorized his trades. In that instance, the Journal would not have been deceived, as O'Hagan requires. Winans' trades would not have constituted an improper conversion of nonpublic information, moreover, so that the essential breach of fiduciary duty would not be present. Again, however, from an investor's perspective, it would not seem to matter whether Winans's trades were authorized or not. Finally, conduct that should be lawful under the misappropriation theory is clearly proscribed by Rule 14e-3. A takeover bidder may not authorize others to trade on information about a pending tender offer, for example, even though such trading might aid the bidder by putting stock in friendly hands. If the acquisition is to take place by means other than a tender offer, however, neither Rule 14e-3 nor the misappropriation theory should apply. From an investor's perspective, however, the form of the acquisition seems just as irrelevant as the identity of the inside trader.

All of these anomalies, oddities, and incongruities have crept into the federal insider trading prohibition as a direct result of Chiarella's imposition of a fiduciary duty requirement. None of them, however, are easily explicable from either an investor protection or a confidence in the market rationale.

\section{Injury to the issuer}

Unlike many forms of tangible property, more than one person can use information without necessarily lowering its value. If a manager who has just negotiated a major contract for his employer then trades in his employer's stock, for example, there is no reason to believe that the manager's conduct necessarily lowers the value of the contract to the 


\section{Research handbook on insider trading}

employer. But while insider trading will not always harm the employer, it may do so in some circumstances.

a. Delay If a manager discovers or obtains information (either beneficial or detrimental to the firm), she may delay disclosure of that information to other managers so as to assure herself sufficient time to trade on the basis of that information before the corporation acts upon it. Even if the period of delay by any one manager is brief, the net delay produced by successive trading managers may be substantial. Unnecessary delay of this sort harms the firm in several ways. The firm must monitor the manager's conduct to ensure timely carrying out of her duties. It becomes more likely that outsiders will become aware of the information through snooping or leaks. Some outsider may even independently discover and utilize the information before the corporation acts upon it. Although delay is a plausible source of harm to the issuer, its importance is easily exaggerated. The available empirical evidence scarcely rises above the anecdotal level, but does suggest that measurable delay attributable to insider trading is rare. ${ }^{63}$ Given the rapidity with which securities transactions can be conducted in modern secondary trading markets, moreover, a manager need at most delay corporate action long enough for a five minute telephone conversation with her stockbroker. Delay (either in transmitting information or taking action) also often will be readily detectable by the employer. Finally, and perhaps most importantly, insider trading may create incentives to release information early just as often as it creates incentives to delay transmission and disclosure of information.

b. Interference with corporate plans Trading during the planning stage of an acquisition is a classic example of how insider trading might adversely interfere with corporate plans. If managers charged with overseeing an acquisition buy shares in the target, and their trading has a significant upward effect on the price of the target's stock, the takeover will be more expensive. If their trading causes significant price and volume changes, that also might tip off others to the secret, interfering with the bidder's plans, as by alerting the target to the need for defensive measures.

The risk of premature disclosure poses an even more serious threat to corporate plans. The issuer often has just as much interest in when information becomes public as it does in whether the information becomes public. Suppose Target, Inc., enters into merger negotiations with a potential acquirer. Target managers who inside trade on the basis of that information will rarely need to delay corporate action in order to effect their purchases. Having made their purchases, however, the managers now have an incentive to cause disclosure of Target's plans as soon as possible. Absent leaks or other forms of derivatively informed trading, the merger will have no price effect until it is disclosed to the market, at which time there usually is a strong positive effect. Once the information is disclosed, the trading managers will be able to reap substantial profits, but until disclosure takes place, they bear a variety of firm-specific and market risks. The deal, the stock market, or both may collapse at any time. Early disclosure enables the managers to minimize those risks by selling out as soon as the price jumps in response to the announcement.

63 Michael P. Dooley, Enforcement of Insider Trading Restrictions, 66 Va. L. Rev. 1, 34 (1980). 
If disclosure is made too early, a variety of adverse consequences may result. If disclosure triggers competing bids, the initial bidder may withdraw from the bidding or demand protection in the form of costly lock-ups and other exclusivity provisions. Alternatively, if disclosure does not trigger competing bids, the initial bidder may conclude that it overbid and lower its offer accordingly. In addition, early disclosure brings the deal to the attention of regulators and plaintiffs' lawyers earlier than necessary. Although insider trading probably only rarely causes the firm to lose opportunities, it may create incentives for management to alter firm plans in less drastic ways to increase the likelihood and magnitude of trading profits. For example, trading managers can accelerate receipt of revenue, change depreciation strategy, or alter dividend payments in an attempt to affect share prices and insider returns. Alternatively, the insiders might structure corporate transactions to increase the opportunity for secret keeping. Both types of decision may adversely affect the firm and its shareholders. Moreover, this incentive may result in allocative inefficiency by encouraging over-investment in those industries or activities that generate opportunities for insider trading.

c. Injury to reputation Insider trading by corporate managers supposedly casts a cloud on the corporation's name, injures stockholder relations, and undermines public regard for the corporation's securities. ${ }^{64}$ Reputational injury of this sort could translate into a direct financial injury by raising the firm's cost of capital. Because shareholder injury is a critical underlying premise of the reputational injury story, however, this argument would appear to collapse at the starting gate. As we have seen, it is very hard to create a plausible shareholder injury story.

\section{A Public Choice Theory Analysis of Insider Trading Regulation}

Some critics of the insider trading prohibition contend that the prohibition can be explained by a public choice-based model of regulation in which rules are sold by regulators and bought by the beneficiaries of the regulation..$^{65}$ On the supply side, the federal insider trading prohibition may be viewed as the culmination of two distinct trends in the securities laws. First, as do all government agencies, the SEC desired to enlarge its jurisdiction and enhance its prestige. Administrators can maximize their salaries, power, and reputation by maximizing the size of their agency's budget. A vigorous enforcement program directed at a highly visible and unpopular law violation is surely an effective means of attracting political support for larger budgets. Given the substantial media

64 Compare Diamond v. Oreamuno, 248 N.E.2d 910, 912 (N.Y. 1969) (discussing threat of reputational injury) with Freeman v. Decio, 584 F.2d 186, 194 (7th Cir. 1978) (arguing that injury to reputation is speculative).

${ }_{65}$ This section focuses on slightly different, but wholly compatible, stories about insider trading told by Professor Michael Dooley and Professors David Haddock and Jonathan Macey. Dooley's version explains why the SEC wanted to sell insider trading regulation, while Haddock and Macey's explains to whom it has been sold. See Michael P. Dooley, Fundamentals of Corporation Law 816-57 (1995); David D. Haddock and Jonathan R. Macey, Regulation on Demand: A Private Interest Model, with an Application to Insider Trading, 30 J.L. \& Econ. 311 (1987); see also Jonathan R. Macey, Insider Trading: Economics, Politics, And Policy (1991). 
attention directed towards insider trading prosecutions, and the public taste for prohibiting insider trading, it provided a very attractive subject for such a program.

Secondly, during the prohibition's formative years, there was a major effort to federalize corporation law. In order to maintain its budgetary priority over competing agencies, the SEC wanted to play a major role in federalizing matters previously within the state domain. Insider trading was an ideal target for federalization. Rapid expansion of the federal insider trading prohibition purportedly demonstrated the superiority of federal securities law over state corporate law. Because the states had shown little interest in insider trading for years, federal regulation demonstrated the modernity, flexibility, and innovativeness of the securities laws. The SEC's prominent role in attacking insider trading thus placed it in the vanguard of the movement to federalize corporate law and ensured that the SEC would have a leading role in any system of federal corporations law.

The validity of this hypothesis is suggested by its ability to explain the SEC's devotion of significant enforcement resources to insider trading during the 1980s. During that decade, the SEC embarked upon a limited program of deregulating the securities markets. Among other things, the SEC adopted a safe harbor for projections and other soft data, the shelf registration rule, and the integrated disclosure system, and expanded the exemptions from registration under the Securities Act. At about the same time, however, it adopted a vigorous enforcement campaign against insider trading. Not only did the number of cases increase substantially, but the SEC adopted a "big bang" approach under which it focused on high visibility cases that would produce substantial publicity. In part this may have been due to an increase in the frequency of insider trading, but the public choice story nicely explains the SEC's interest in insider trading as motivated by a desire to preserve its budget during an era of deregulation and spending restraint.

The public choice story also explains the SEC's continuing attachment to the equal access approach to insider trading. The equal access policy generates an expansive prohibition, which federalizes a broad range of conduct otherwise left to state corporate law, while also warranting a highly active enforcement program. As such, the SEC's use of Rule 14e-3 and the misappropriation theory to evade Chiarella and Dirks makes perfect sense. By these devices, the SEC restored much of the prohibition's pre-Chiarella breadth and thereby ensured that its budget-justifying enforcement program would continue unimpeded.

Turning to the demand side, the insider trading prohibition appears to be supported and driven in large part by market professionals, a cohesive and politically powerful interest group, which the current legal regime effectively insulates from insider trading liability. Only insiders and quasi-insiders such as lawyers and investment bankers have greater access to material nonpublic information than do market professionals. By basing insider trading liability on breach of fiduciary duty, and positing that the requisite fiduciary duty exists with respect to insiders and quasi-insiders but not with respect to market professionals, the prohibition protects the latter's ability to profit from new information about a firm.

When an insider trades on an impersonal secondary market, the insider takes advantage of the fact that the market maker's or specialist's bid-ask prices do not reflect the value of the inside information. Because market makers and specialists cannot distinguish insiders 
from non-insiders, they cannot protect themselves from being taken advantage of in this way. When trading with insiders, the market maker or specialist thus will always be on the wrong side of the transaction. If insider trading is effectively prohibited, however, the market professionals are no longer exposed to this risk.

Professional securities traders likewise profit from the fiduciary duty-based insider trading prohibition. Because professional investors are often active traders, they are highly sensitive to the transaction costs of trading in securities. Prominent among these costs is the specialist's and market maker's bid-ask spread. If a ban on insider trading lowers the risks faced by specialists and market makers, some portion of the resulting gains should be passed on to professional traders in the form of narrower bid-ask spreads. Analysts and professional traders are further benefited by a prohibition on insider trading, because only insiders are likely to have systematic advantages over market professionals in the competition to be the first to act on new information. Market professionals specialize in acquiring and analyzing information. They profit by trading with less well-informed investors or by selling information to them. If insiders can freely trade on nonpublic information, however, some portion of the information's value will be impounded into the price before it is learned by market professionals, which will reduce their returns.

Circumstantial evidence for the demand-side hypothesis is provided by SEC enforcement patterns. In the years immediately prior to Chiarella, enforcement proceedings often targeted market professionals. The frequency of insider trading prosecutions rose dramatically after Chiarella held insider trading was unlawful only if the trader violated a fiduciary duty owed to the party with whom he trades. Yet, despite that increase in overall enforcement activity, there was a marked decline in the number of cases brought against market professionals.

In his contribution to this volume, Todd Henderson updates the public choice analysis recounted above. Henderson documents a significant change in the target of enforcement in civil and criminal cases, finding that over the past three decades the emphasis of enforcement has shifted more towards securities market professionals instead of corporate insiders. Is the enforcement of insider trading laws in the public interest? One approach to answering this question is to examine the pattern of enforcement to see if it is better explained by a public interest account or by the balance of private interests with a stake in the enforcement of these laws. As described above, David Haddock and Jonathan Macey took stock of insider trading laws in the early 1980s, and concluded that it was best explained by a private interest account. They observed the pattern of enforcement emphasized prosecuting corporate executives instead of securities trading professionals, but noted a more even treatment in cases involving corporate takeovers. This was best explained by the fact that at the time corporate insiders had little stake in insider trading enforcement in light of their paucity of trading activity, but were threatened by corporate takeovers. Henderson's chapter updates the Haddock and Macey account by tracking the changes to private interests since 1983 and seeing whether they explain the current pattern of enforcement. Securities professionals are much more likely to be prosecuted today, both in civil and criminal cases, and this can be explained by the fact that corporate insiders now trade in much greater amounts and the threat from trading as a takeover device is stronger. Henderson therefore concludes that the private interest account fits as well today as it did three decades ago. 


\section{Research handbook on insider trading}

\section{An Alternative Disclosure-Based Regime}

Thomas Lambert's contribution to this volume begins by arguing that insider trading may create both social harms and social benefits. Attempts to regulate such "mixed bag" business practices may err in two directions. They may wrongly permit or encourage socially undesirable instances of the practice at issue. Alternatively, they may wrongly condemn or deter socially desirable instances. Attempts to avoid error in one direction or another (error costs) by heightening the liability inquiry will tend to increase the regulatory regime's administrative costs (decision costs). Decision theory therefore calls for regulating mixed bag practices under a regime that minimizes the sum of error and decision costs.

Adjudged under the decision-theoretic criterion, Lambert argues, both the current regime for regulating insider trading in the United States and the more restrictive approach apparently favored by enforcement agencies are failures. The "contractarian" approach favored by many law and economics scholars would represent an improvement over both approaches, but it, too, may be suboptimal.

Lambert therefore advocates an optional, disclosure-based regulatory regime. Such an approach would (1) enhance the market efficiency benefits of insider trading by facilitating "trade decoding," while (2) reducing potential costs stemming from deliberate mismanagement, disclosure delays, and infringement of informational property rights. 